ISSN 2236-0859

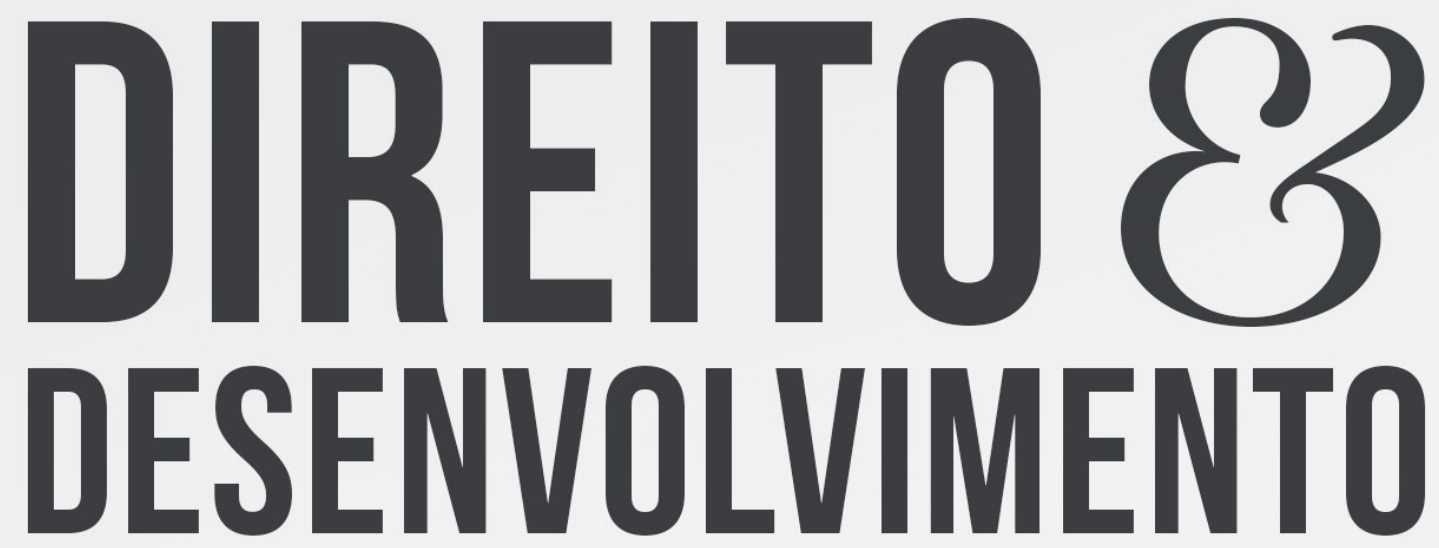

REVISTA DO PROGRAMA DE PÓS-GRADUAÇÃO EM DIREITO MESTRADO EM DIREITO E DESENVOLVIMENTO SUSTENTÁVEL

FROM STATE PLANNING TO PUBLIC CONTRACTING: A NECESSARY OPTION FOR SUSTEINABLE DEVELOPMENT

BRUNO GOMES BAHA

ANDRÉ RICARDO FONSECA DA SILVA 


\title{
FROM STATE PLANNING TO PUBLIC CONTRACTING: A NECESSARY OPTION FOR SUSTEINABLE DEVELOPMENT
}

\section{DO PLANEJAMENTO ESTATAL À CONTRATAÇÃO PÚBLICA: UMA NECESSÁRIA OPÇÃO PELO DESENVOLVIMENTO SUSTENTÁVEL}

Recebido: 04/11/2019

Aprovado: 04/11/2019
Bruno Gomes Bahia ${ }^{1}$ André Ricardo Fonseca da Silva ${ }^{2}$

\begin{abstract}
:
This article is about analyzing the state dynamics that goes from planning, through the public budget, to materialize with public procurement. Its focus is to find, in each of these institutes linked to the economic and financial order, its point of intersection with sustainable development, defended in the present work as one of the fundamental principles of the Republic, through the intertwining of arts. 1ㅜㅜ $3^{\circ}, 170$ and 225 of the Constitution. From this, it sheds some light on what is called sustainable public procurement, calling attention to the state purchasing power, which, because of the large volume of resources it moves, can be an important tool to induce and influence the market to a more sustainable behavior. Thus, recognizing the socio-environmental crisis suffered by the planet, it is intended to articulate forces to develop a culture oriented to reconcile the dimensions of sustainability, especially its economic, social and environmental aspects. Thus, adopting a qualitative research methodology of bibliographic review, it was concluded that, from planning to hiring, the State necessarily needs to opt for sustainable development, under penalty of aggravation of the socio-environmental crisis or even make the effort in sustainable public procurement mere initiatives in the field of public administration.
\end{abstract}

Keywords: Planning. Sustainable Public Procurement. Sustainable Development.

\section{RESUMO:}

Este artigo trata de analisar a dinâmica estatal que vai desde o planejamento, passando pelo orçamento público, até se concretizar com a contratação pública. Seu foco é encontrar, em cada um desses institutos ligados a ordem econômica e financeira, seu ponto de intersecção com o desenvolvimento sustentável, defendido, no presente trabalho, como um dos princípios

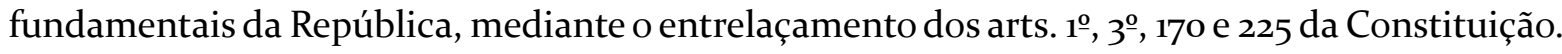
A partir disso, são lançadas algumas luzes no que se denomina de contratação pública sustentável, chamando atenção para o poder de compra estatal, o qual, em razão do grande volume de recursos que movimenta, pode ser uma importante ferramenta para induzir e influenciar o mercado a um comportamento mais sustentável. Assim, reconhecendo a crise socioambiental sofrida pelo planeta, pretende-se articular forças para que se desenvolva uma cultura orientada a conciliar as dimensões da sustentabilidade, notadamente seus aspectos econômicos, sociais e ambientais.

1 MSc in Law and Development at University Center of João Pessoa - UNIPÊ (2019), Specialist in Public Law (2010), Specialist in Tax Law (2012), Specialist in Administrative Law (2015), Graduated in Law at UFBA (2010), member of the Agro-Environmental Extension Project and Public Lawyer. E-mail: bgomesbahia@yahoo.com.br

2 PhD in Public Policies and Human Education (UERJ). Master in Legal Sciences (UFPB). Specialist in Municipal Law (UNIPE). Graduated in Law (UNIPE). Coordinator of the On-Theology Course at the Faculdade Internacional Cidade Viva-FICV. Permanent Professor of the Master in Law of UNIPE. Adjunct Professor of UNIPE Graduation. Editor-in-Chief of the Scientific Journal: Law and Development of PPGD / UNIPE (ISSN 2236-0859). E-mail: professor.andrefonseca@gmail.com 
Assim, adotando uma metodologia de pesquisa qualitativa de revisão bibliográfica, concluiuse que, desde o planejamento até a contratação, o Estado necessariamente precisa optar pelo desenvolvimento sustentável, sob pena de agravamento da crise socioambiental ou, ainda, de tornar o esforço em torno das contratações públicas sustentáveis meras iniciativas no âmbito da Administração Pública.

Palavras-chave: Planejamento. Contratação Pública Sustentável. Desenvolvimento Sustentável.

\section{INTRODUCTION}

The world is currently undergoing severe economic, social and environmental disturbances which, combined, have made us question the future-oriented development model.

In this sense, the environmental crisis issue is no longer hermetic and linked only to environmental problems. The issue is cross-sectional, connecting itself to other societal aspects and elements.

One can no longer say that a nation is developed when its ecosystem languishes, and the individual quality of life is threatened. A country cannot be considered rich if an abyss of social inequality stands among its citizens.

In Brazil, our Political Charter establishes, in its $3^{\text {rd }}$ article, that goals of our Republic are the construction of a free, just and solidary society which guarantees, in addition to that, national development, the eradication of poverty and the reduction of social and regional inequality.

Linked to these purposes, the Constitutional Congress, in article 225, has shown that, as a pathway to development, everyone has the right to a ecologically balanced environment, crucial to a healthy quality of life, being a duty of the public authorities and the collectivity to defend and preserve it for the present and future generations.

Besides, in observance of the section on economic and financial order and considering the aforementioned State duties and ethic objectives, there's nothing more evident than demanding from it a necessarily planned performance, as exactly stated on article 174 .

Given these points, the purpose with the present article is to verify if the economic and financial order from the 1988 Constitution, beginning with the activity of state planning up to its accomplishment - with public contracting - would be necessarily linked to a road leading to sustainable development.

For this purpose, it is necessary to inform that the choice of planning and public contracting institutes was not random. It concerns two extremes of state dynamics, in which the first deals with generic and abstract actions, geared towards establishing aims and broad objectives for the State. The second, in turn, reveals itself as one of the most concrete acts of the Public Administration, having in its ultimate extent, the goal of accomplishing effectively and positively the planning set before.

In this desideratum, this article had as a first objective expounding on the evolution of the concept of economic development, going through the study of sustainable development dimensions to an analysis of state planning and public contracting, with reference to the evaluative and axiological directives of the 1988 Constitution.

Furthermore, concerning the methodology, qualitative researching was adopted, through a technique of bibliographical theme revision, in a clear intent to link sustainable development, State planning and public contracting. 
Finally, the present article is divided into five topics, in which the first and the last deal with the introduction and final considerations, respectively. The second concerns the principle of sustainable development in the 1988 financial and economic order, while the third examines state planning and its connection to development, and the fourth focuses in public contracting from a perspective of sustainability.

\section{SUSTEINABLE DEVELOPMENT IN THE 1988 FINANCIAL AND ECONOMIC ORDER.}

This topic is justified by the need of analyzing the grounds and origins of development, notably its breaking away from an ideal of exclusively economic development until what is currently known as sustainable development.

From there, an evaluation of the very postulate of sustainability from the standpoint of the Federal Constitution is intended, especially in the title relating to Economic and Financial Order, thereby laying ground for the study of state planning and public contracting.

\subsection{From growth to development}

According to Miranda (2018), up until the half of the past century, development has been synonymous with economic growth, in which the main way of attaining it would be through the accomplishment of progress. This led governments to put faith in polities and actions geared toward intensive use of resources to increase production and wealth, by creating industries and fostering consumption.

In this sense, countless transformations have managed to mark the mentioned period, especially due to a surge in conscientization that begun to question this growth model, based, so far, in the irrational and unsustainable increase in production and consumption. Environmental disasters and catastrophes revealed mankind's inability in managing such exploitation of natural and social resources, drawing attention to the plight suffered by the planet.

From there, Varella (2003) explains that the confrontation with the environmental crisis has sparked a standoff between Northern and Southern countries. The former, remarking the loss of its populations' quality of life, became proponents of a global pact in defense of the environment. The latter, however, still suffering from severe social problems, demand the right to development as a case for searching economic growth.

On this matter, Granziera (2014, p. 36) reveals that the shock of interests was so intense that Southern countries have formally disavowed any action that might impede its growth, "even if it meant having to cope with environmental problems."

On the other hand, movements such as the Rome Club (1968), the Stockholm Conference (1972), the Brundtland Report (1987), ECO-92, the Millennium Declaration (2000), RIO+10 and the United Nations Summit (2015) have been of significant importance in questioning and making a stand against the then-current model, creating a split between the concepts of growth and development.

The international community, in its turn, began demanding a paradigm shift, in a way that development would no longer be measured and linked only to strictly economic criteria, claiming a multidimensional amalgamation with social and environmental aspects. 
Following such trend, the right to development begins to lose ground in the realm of International Economics while gaining, at the same time, relevance in International Environmental Law. This made the growing decay of the planet become a matter of concern to all, no longer representing an economic conflict between North and South (VARELLA, 2003, p. 31).

Corroborating with this analysis, Milaré (2014) clarifies that the myth of mere growth is being increasingly (albeit slowly) reconsidered by society, scanning for alternative measures able to conciliate full development, environmental preservation and quality of life improvement.

Following this rationale, Nusdeo (2002) advocates the need of imposing a conceptual distinction between growth and development. The latter, apropos, would be deeper than the former, revealing itself as a pathway or passage, composed by many steps, starting from a state of underdevelopment to attain a "developed" status. In this desideratum, development is linked to structural modifications not only of economic, but also environmental and social nature.

In addition, to the author growth concerns solely the availability of goods and services, without effectively implying structural and qualitative change in a nation. This would represent, therefore, "an upsurge, a cycle, and not a stable process." (NUSDEO, 2002, p. 19)

Development, effectively, is more complex, accounting for ideas of wellbeing, life conditions improvement, freedom, acquisition of human capacities, wealth distribution, poverty reduction, plurality, environmental protection, HDI, among others. (FEITOSA, 2013).

Feitosa (2013), with this outline, sums up this conceptual shift from growth to development given an inflection of economic into law. According to the author, this trajectory begins with the illuminist ideal of progress, going through the understanding of growth as a durable, accumulative and speculative strategy, arriving at the present concept of development, "considered as a plural inclusion and capacity recuperation process, which guarantees and (is) guaranteed by rights" (FEITOSA, 2013, P. 177).

Therefore, from this context and this conceptual shift the definition of economic development takes form, attaching itself to new aspects, notably social and environmental ones, creating the idea of sustainable development, which is the subject of the next topic.

\subsection{Susteinable development: environmental, social and economic dimensions}

After its origins on the narrow definition of economic growth, sustainable development undergoes a conceptual evolution, relating to other aspects of life and society, and gaining notoriety with the Brundtland Report (Our Common Future), elaborated by the United Nations World Commission on Environment and Development.

According to the mentioned document, sustainable development is that "which allows the present generation to satisfy its needs, without compromising other generations' satisfaction of their own." (BRUNDTLAND COMISSION, 1991, p. 46)

Such definition, although criticized by many authors (such as Arthur Lyon Dahl, Reinaldo Dias, Amartya Sen, Maria Helena Martins Brasileiro, and others), had an important role in publicizing the debate on the matter, drawing attention, in its' first moments, to the search for balance between economic development and environmental preservation. (MIRANDA, 2018)

Further on, the discussion concerning sustainable development has attained greater breadth and cross-secionality, evoking Human Rights as well. According to Granziera (2014), the Rio/92 Declaration, for instance, has set a close relation between poverty and environmental 
decay, in a such wat that one can only speak of a healthy environment if social rights are considered as well.

It is exactly on this expansion and broadening that Feitosa (2013) explains that it was exactly because of the collapse of the market's deregulating structures, the worsening of the environmental crisis and the greater awareness of the dangers of inequality, that the concept of sustainable growth detaches itself from a merely environmental standpoint to embrace human and social aspects.

With this, sustainable development is then understood in a way aiming at conciliating social, environmental and economic dimensions, forming the so-called the tripe bottom line. (MIRANDA, 2018)

Under such a perspective, Mendonça (2018), emphasizing the environmental dimension, explains that in this task of balancing, the promotion of sustainable development is related to the search for sustainable patterns of consumption and production. Its purpose should head towards an increase in the efficiency of energy usage with the goal of reducing the pressure on the environment, as well as pollution and the depletion of natural resources, given that the current model places the very survival of mankind at risk.

Freitas (2019, p. 74), following this trend, warns that "there can be no worthy longevity in a degraded environment" and that "there can't even be human life with no careful protection of environmental sustainability", as "either the quality of the environment must be protected or there will simply be no future for our species".

From the standpoint of the economic dimension, sustainability poses a double challenge, as stated by Cruz and Ferrer (2015): on one hand, there's the intention of increasing wealth generation in an environmentally sustainable way and, on the other, finding mechanisms for its fair distribution. Some measures refer to these purposes, such as the need to invest in "green" technology sectors and in renewable energy sources, prohibiting abusive and unsustainable practices, as well as having in mind a new model for generation of wealth, away from classic consumerist patterns.

Freitas (2019, p. 75), in this way, explains that the economic dimension of sustainability cannot be detached from rationality and the measurement of ecosystemic consequences. That is, transactions must deal directly with externalities in order to repress dysfunctionalities, reducing waste and promoting robust investments in educational improvement, increasing individual income, "in a cost-benefit equation that leans towards positive externalities".

From the social dimension standpoint, however, sustainable development is linked, more intensely, to the principle of human dignity, in a way that, according Freitas (2019, p. 65), "an excluding, insensible and inequitable development model cannot be tolerated".

In this phase, the task at hand is aligning the exercise of fundamental rights with the formulation of public policies that can effectively reduce poverty and inequality, without implicating a mere growth process, dissociated from environmental protection.

Such dimensions, as observed by the author, are entangled, as they are not a mere union of sparse characteristics, but of articulated and systematized aspects, in a mutual and complex relationship between individuals, as well as between them and the planet.

Therefore, it is from this study of sustainability dimensions that the importance of discussing whether Brazil is observing, through its Political Charter, environmental and social problems, becomes clear. That given, it is essential to analyze if the Economical and Financial Order established by the 1988 Constitution is aligned with sustainable development, a relation that will be addressed in the following subtopic. 


\subsection{An economic and financial order geared toward sustainable development}

With the unveiling of the origins and dimensions of sustainable development, it is now suitable to investigate if the Constitution, specially in its $7^{\text {th }}$ title, concerning the economic and financial order, has embraced sustainability as an orienting vector of state activity, which will allow us to lay the ground for the analysis of our following topics.

Indeed, article 1, clause III of the Constitution already stated its first sign of favoring sustainability, by funding the Democratic Rule of Law in the dignity of the human person. In this continuous act, article 3 states the fundamental objectives of the Republic, highlighting, among them, the making of a free, just, and solidary society, which can uphold national development, eradicate poverty and reduce social and regional inequalities.

Following this line of thought one may say that the referred article is a synthesis of all dimensions of sustainable development. After all, it would not be possible to plan for a just society if economic activity is detached from the reduction of poverty and environmental problems.

Moreover, a nation cannot be classified as developed if there linger social and regional inequalities among its citizens. There won't be quality of life if the ecosystem languishes. There is no possibility in sight to ensure national development should human dignity and a solidary society not be ensured as well.

Therefore, it is possible to affirm that the Constitution, through a simple interpretation of its fundamental principles, as expressed in its first and fourth articles, is committed to sustainable development. Such an inference, it should be said, is quite relevant, since it is usual for the interpreter, while analyzing the constitutional section on economic and financial order, to make a narrow and non-systematized rendition, forgetting the foundations and objectives.

From the article 170 , dealing with general principles of economic activity, the Constitution did not forget its' founding goals by stating in its beginning that the purpose of economic activity is ensuring a dignified existence to all, as demanded by social justice.

Besides, clauses VI and VII highlight the status the Constitution grants to sustainable development, explicitly indicating that the economic order should observe environmental protection and the reduction of social and regional inequalities.

This circumstance, consequently, reveals the concern of the founding constitutional congress in correcting the mistakes of an economic model that ignores biological, physical and chemical limitations of the ecosystem. (PAIVA JÚNIOR, 2018)

With this desideratum, article 225, although concerning matters outside the section of economic order, attaches itself, in a systematical and teleological way, to the beginning and clause VI of article 170, establishing that everyone has the right to an ecologically balanced environment that ensures a healthy quality of life, imposing to the public authorities and the collectivity the duty to defend and preserve it for the present and future generations.

Paiva Júnior (2018, p. 115), in this sense, states that "if the economic order is geared towards the accomplishment of a dignified existence and social justice, its practice cannot result in the reduction of the population's quality of life", being necessary, therefore, to strive for balance among the dimensions of sustainable development.

Freitas (2019), in a study on the constitutional value of sustainable, explains that the systematic topic intertwining of articles 3, 170, VI and 225 of the Charter is exactly what adamantly determines the orientation of the Brazilian State, along with its economic and financial order, towards continuous and lasting development, able to reduce inequality; in other words, sustainable development. 
Corroborating this understanding, Silva (2004, p. 63) highlights that the constitutional section on Economic Order shows that the national wealth and production goods should be compatible "with the attainment of quality of life throughout the entire population, considering the perspective of working in equitable conditions with other social strata." The author, furthermore, concludes that, in order to make this possible, state action should be guided by the fundamental principle of national development.

Additionally, he states that "the entire constitutional order, concerning Section VII of the Economic Order, was conceived and constitutionally structured in order to make national development possible", seeking to accomplish the fundamental tenets of the Republic. (SILVA, 2004, p. 63) Here, however, we have made a small addendum to Silva's thinking, given that, as explained before by Freitas, such national development can only be the sustainable one.

Adri (2007, p. 91), while analyzing the matter, advocates that the entire constitutional corpus "shows that economic order and the State can only have their raison d'être in serving the human being, its citizens, and not the other way around."

In this way, development and, consequently, the constitutional economic order, observed by a strictly economic perspective, ignoring dignity, life quality and environmental balance tenets, would have no legitimacy to accomplish the founding goals of the Republic, especially considering articles 1 , III and 3.

Vieira (2010), on this matter, explains that the telos of economic order is to ensure a dignified existence to all, as dictated by social justice, observing environmental protection (beginning and clause Vi of article 170), it is therefore an objective of an ecologically balanced environment and essential to a healthy quality of life.

Finally, the referred author concludes that, through a contextualized analysis, the constitutional economic system brings forth, "in an irreversible and uncontestable way, the sustainable development model is the preferred one by systematical interpretation of the norms stated in articles 170 and 225". (VIEIRA, 2010, p. 11)

Therefore, considering the foregoing, it is possible to affirm that sustainable development is more than compatible with economic and financial order, it is the orientation vector to be sought by the Brazilian state. As such, there is no possibility for development that is not in line with the multidimensionality of sustainability, conciliating the complex environmental, social and economic aspects.

\section{STATE PLANNING}

Considering the prior investigation had as its goal demonstrating the necessary option by the constitutional congress for sustainable development, the present topic intends to analyze one of these economic and financial order institutes, namely state planning.

Therefore, some preliminary general observations will be made concerning its historical evolution, definition and nature, in the scope of the Brazilian legal system. Afterwards, it is intended to relate development to planning, with greater attention in connecting the matter with public contracting.

\subsection{Historical evolution, concept and juridical nature}

It is curious to observe that the Brazilian state planning is a relatively young matter to be treated in the constitutional corpus. Cardoso Júnior (2011) notes that from 1889 (the First 
Republic) to 1930 there was no state planning, with complete omissions of the then-effective Constitutions about the subject.

Afterwards, in the period between 1933 and 1955, known as the Vargas Era, Brazil lived the period of Non-Systemic Planning, marked by the SALTE Plan, which aimed to answer an industrialization context, by creating the first state companies (such as Petrobras, BNDE and Vale do Rio Doce).

From 1956 to 1964, the author points that the country pursued Discretionary Planning, which had a more present and lasting character, albeit freely adopted by the incumbent. This period was marked by developmentalism and the ${ }_{3}$ Goals Plan of Juscelino Kubitschek. From 1964 to 1979, during the military regime, Planning became technocratic and bureaucratic, when the government assumed everything could be solved by the know-how conceived by its authoritarian bureaucrats. In this period the Superior School of War (Escola Superior de Guerra) was created and the PAEG (Government Economic Action Program - Programa de Ação Econômica do Governo) and the second PND (National Development Plan - Plano Nacional do Desenvolvimento).

From 1980 to 1989 , the referred author defines the moment of planning as a series of attempts to implement stabilization plans, given that in the redemocratization period there were attempts to implement plans Cruzado (1986), Bresser (1987), Verão (1988) and Maílson (1989), which were, in their turn, not successful as promised. However, from 1990, an year marked by democratic consolidation and managerial reforms in the state, the scholar notes that since 1994, with plan Real, state planning was marked, effectively, by its stabilization plans, especially with the obligatoriness of the public authorities to elaborate, every 4 years, pluriannual plans.

After the very idea of planning having evolved throughout Brazilian history, the 1988 Constitution has addressed it in the economic and financial order section, especially in article 174 .

\footnotetext{
Art. 174. As a normative agent and regulator of economic activity, the State will exercise, as written in law, the functions of surveillance, stimulation and planning, the latter being determinant for the public sector and advisory for the private sector.

$\S 1^{\mathbf{o}}$ The law will establish the directives and grounds of the planning of balanced national development, which will incorporate and make the national and regional developments plans compatible.
}

Hence, it became a subject of greater study by the doctrine. Meirelles (2014, p. 844), for instance, defines planning as the "study and establishing of directives and goals that will orient government action, through a general government plan (...)"

Grau (2006), in the same vein, states that planning is a rational action characterized by the signaling of future social and economic behaviors, with goal-making and the setting of coordinated means of action.

By such definition, the scholar (2006) advocates that the nature of planning is not intervention, but a technique or rational action method that aims to qualify state intervention. Such line of thought however, is not unanimous, with the opposing argument that with article 174 itself the constitutional congress intended to characterize planning as one the intervention forms. According to Adri, the legal corpus does not confer to the mentioned institute a generic idea of a technical act of mere administrative and financial act. His position follows:

It does not suit dynamism and efficacy that the juridical order confers planning the idea that it is a technical act void of ideological content, being granted, solely, the nature of 


\begin{abstract}
administrative and public-resource financial action, with no interference or association with social control and demands, which would result in its neutrality (...)

Planning presupposes political action with its own purpose and dynamizing status, which assimilates the diversity of choices facing certain objectives as identified by standards chosen by society. (ADRI, 2007, p. 123)
\end{abstract}

However, for the purposes of the present article, the definition of Eros Roberto Grau will be adopted, since, for us, planning is a mean of the State to achieve sustainable development. It does not seem possible to intervene in economy with the purpose of planning for the sake of it, as an end on itself. The activity of planning does not derive from Law, but from other sciences, such as Economy, Political Science, Statistics, Accounting and many others, which seek to establish techniques and methods so that the public authorities can, prior to intervention, rationally outline practicable goals.

Besides, from such conception, planning becomes the directive vector of the entire Administration, spreading it across the state structure, avoiding its distance from reality and the administrative routine, in a way to encourage the public manager to adopt a more professional and managerial performance, closer to the State goals and objectives.

Furthermore, as warned by Marrara (2011), from adopting this definition, the theme of planning is no longer linked to an ideological discussion between economic liberals and socialists, given that its conception is primarily technical, inasmuch the State cannot profit from disorganization, randomness and inefficiency in the achievement of its public policies.

Thus planning can be understood as a technique or method that allows the State, in rational, systematized and cross-sectional action, to project goals and objectives geared towards formulating public policies that, necessarily, pursue sustainable development, a theme that will be further described in the next topic.

\title{
3.2 State planning: a necessary option for the sustainable development of the Brazilian state
}

As described, state planning was considered in the economic and financial order, specially in article 174 of the Constitution. However, the provision represents solely the opening of the debate, since the act of planning is found throughout the entire constitutional text and, as intended to be demonstrated here, the entire Charter is oriented towards sustainable development.

Anyway, the starting point will necessarily be article 174. In its beginning, it is written that "As a normative agent and regulator of economic activity, the State will exercise, as written in law, the functions of surveillance, stimulation and planning, the latter being determinant for the public sector and advisory for the private sector."

According to Silva (2004), by reading the referred provision, the Constitution has listed two roles of state intervention: normative and regulating agent, along with the three functions to carry them out: surveillance, stimulation and planning. Here, four relevant observations should be made.

The first one is that the State, by exercising its planning function, has the objective of qualifying and rationalizing the interventive roles of the State, either as a normative agent or as a regulator of economic activity, which indicates the appropriateness of the concept by Eros Roberto Grau.

Secondly, to the author (SILVA, 2004, p. 105) although the Constitution has declared that surveillance, stimulation and planning functions will be exercised as written in law, 
"by foreseeing the determining character of planning to the public sector, the constitutional congress has vested the norm of article 174 with a self-executing character.

Thirdly, when the text informs that the act of planning is determinant for the public sector and advisory for the private sector, it means that the State may suggest goals and ways, to which he will be attached and must therefore strive to enforce them; it, however, may not coerce them in any way from the private initiative. (TAVARES, 2011)

Besides, the public authorities may create mechanisms and incentives so that the private agent may collaborate with its planning, but always voluntarily, given that the principle of free initiative is also a constitutional tenet.

In a fourth commentary on the beginning of article 174, Tavares (2011) explains that some scholars, such as Miguel Reale and Oscar Dias Corrêa, distinguish planning from planification. While the former is advisory to the private sector, planification is compulsory and enforceable on the entire collectivity, as experienced in the former USSR.

Now, heading for $\S 1$ of article 174 , the true intention of the constitutional congress is revealed, that being: planning must be geared towards sustainable development. According to the provision, "the law will establish directives and grounds for planning the national balanced development, which will incorporate and make compatible regional and national development plans".

Grau (2006), while commenting the text, argues that $\S 1$ has the purpose of defining and qualifying planning as addressed in the beginning of article 174. Thus, the state will not exercise a function of planning whatever or indiscriminately planning, but of planning "balanced national development", which, as explained by Freitas, can only be sustainable development:

\footnotetext{
Sustainability is, in the Brazilian legal system, among its values, one of constitutional magnitude. Furthermore, it is a "supreme value", when interpreting the Charter as an instrument of long-term social and biological balance.

It is easy to justify: from the introductory statement of the Constitution, development stands out as one of the "supreme values". Which development, may we ask? It cannot be that of the imperious and nature-degrading anthropocentric view, nor that of the insensibility typical of parasitic relations. It is sustainable development, or preferably, sustainability, that appears as a supreme value (FREITAS, 2019, p. 121)
}

Supporting this, Adri (2007, p. 142) also holds that "not any political provision will answer this demand from the constitutional text, but planning geared towards (sustainable) development", which presupposes an articulation of interests guided towards conciliating economic (wealth production), social (wealth distribution) and environmental (importance to healthy quality of life) factors.

Further in this context, Silva (2004, p. 112) comparing the French and Italian experiences, explains that the Brazilian development model "seeks, precisely, the diminishing of local, regional and national differences", since the Federative Republic of Brazil has the ontological and inexcusable duty of ensuring development.

In this view, the public authorities have the moral and legal duty of executing its plan and adopting every providence necessary to its execution, but from the decision to plan, going especially through the (content) elaboration phase, up to its implementation, planning must be oriented towards sustainable development.

That is, fundamental principles, chartered in human dignity, in the making of a just, free and solidary society, in the eradication of poverty and the goal of reducing regional and social inequalities, are the gravitational center of planning. 
From there, every other sphere relating to planning will be necessarily linked to thinking and obliging the duty of sustainability, considering the evident intertwining of articles 3, 170 and 225 of the Constitution.

For instance, when discussing urban planning, article 182 establishes the duty of the state to order urban policy to "the full development of the city's social functions and ensuring its inhabitants wellbeing”. That said, there's a clear link with the aforementioned provisions, in a way that observing the city's social function and ensuring wellbeing is a matter inexcusably linked to sustainable development, in an indicative task of conciliating the social, economic and environmental instances.

In the same way, in thinking economic planning one cannot forget article 170 , which is based in the cherishing of human labor and in free initiative, having as a goal ensuring a dignified existence to all, as demanded by social justice, observing furthermore, environmental protection.

Similarly, by mentioning the planning of the national financing system, article 192 of the Charter states that it will be "structured so as to promote balanced development in the country and serving the collective interests".

If one considers furthermore the educational planning, article 205 states that education "will be promoted and fostered with societal collaboration, seeking full personal development, its preparation to the exercise of citizenship and qualification for work", associating itself clearly with articles 3, 170 and 225 of the Constitution, given that there will be no quality education if no heed is paid, respectively, to the diminishing of inequality, respect to social norms and healthy quality of life (with a balanced environment).

The same happens with scientific and technological planning and innovation, given that articles 218 and 219 set the state duty to relate them to the "country's cultural and socioeconomic development, along with the population's wellbeing and national technologic autonomy", which, combined, represent the dimensions of sustainable development.

The state budgetary and financial planning of the state will be directed towards sustainability as well; the theme, however, due to its strong connection to public contracting, will be addressed in the next topic.

Anyhow, what is evident is the clear and explicit constitutional will in directing state planning, along with all its correlated matters, to sustainable development, thus guided to the ethical environmental duty, the purpose of ensuring everyone a dignified existence, the eradication of poverty and the diminishing of inequality.

\subsection{Budgetary and financial planning: paving the way to sustainable public contracting}

Given that economic and financial order, as well as its institute of state planning, follows the way of sustainable development, it must, coherently, be observing in budgetary planning.

From it, the analysis on financial resource allocation, intended to attain the public policies planned by the state, proves to be of the utmost importance.

As observed by Leite (2017), initially the budget was considered to be a mere accounting piece, detached from the idea of planning, with no goal or objective setting. Hence there was no concern with the true needs of the collectivity. In evolving, discussion began on the budgetprogram model, adopted in Brazil, by which the resource allocation is linked to the objectives, goals and projects of the state plan. 
Pereira (2008), on the other hand, argues that the environmental crisis and social problems experienced by the planet demand another evolution, pursuing the so-called "sustainable budget". With this, it was initially suggested greater investment in personnel improvement (obviously geared towards sustainability) so that there is greater quality in control and evaluation of public expenses. For him, any budgetary destination should be considered in a holistic and integrated way, as performing isolated expenses, without considering the whole (especially its externalities).

Pereira's viewpoint is an interesting one, as the constitutional order would allow such an evolution and budgetary planning, needing only a paradigm shift; not that it is an easy or simple task, especially in the political field, engaging the incumbents, responsible for drafting the budget, in a mindset centered around sustainability.

In Brazil, the budget is expressed, in general terms, in three budgetary laws: the Pluriannual Plan (PPA), the Budgetary Directives Law (Lei de Diretrizes Orçamentárias LDO) and the Annual Budgetary Law (Lei Orçamentária Annual - LOA).

Indeed, the PPA represents long-term strategical planning, elaborated every 4 years (non-coinciding with the presidential mandate), establishing, in generic terms, the goals and objectives of the Administration for capital expenses (relating to investments). The LDO, on the other hand, is short term strategic planning, representing a link between PPA and LOA, establishing, in a summarized way, goals and priorities to the Administration, on top of the financial stimulation agencies application policy (e.g. BNDES, Caixa and Banco do Brasil), LOA, in turn, is the budgetary piece that foresees revenues and sets the expenses of the following accounting period, as guided by the PPA and LDO.

Moreover, they are all linked to article 174, § 1 of the Constitution. Therefore, budgetary planning is tasked with making the national and regional development plans compatible, as, pursuant to article $165, \S 4$, these plans will be elaborated in accord with the PPA.

In addition, $§ 7$ of article 165 meets all that is advocated in this study, since the LOA will have among its functions that of "diminishing interregional inequalities", thus linking itself to article 3 of the Constitution.

In other words, the attainment of fundamental principles of the Republic do not escape the public budget. Plans and programs, along with their expression in budgetary laws, are not an end in themselves. They are means of attaining human dignity, of building a just society, of ensuring a healthy quality of life (with a balanced ecosystem), bent on diminishing inequality.

From there, one may say that an ineffective allocation of resources in programs and actions seeking to accomplish the environmental ethical duty of ensuring an ecologically balanced environment or having the purpose of diminishing social inequalities, would result in standing against the very fundamental principles chartered in the Constitution.

The budget has, therefore, as a mean of making public policies possible, the duty to seek sustainable development and, as observed by Pereira, the analysis of public expense demands a holistic approach, that may integrate social, environmental and economic dimensions.

All things considered; budgetary planning is the strongest link of public contracting. As stated in article 165 , § 10 of the Charter, "the Public Administration has the duty of executing budgetary programs, adopting the necessary means and measures, with the goal of ensuring the effective provision of goods and services to society."

Additionally, one of the ways by which the public authorities may deliver goods and services to society is through public tenders and contracts. Here, one may say, the broad goals and objectives of the State (planning) are joined with the concrete actions meant for the collectivity in the effective acquisition of goods and services. 
It is in this moment that the two extremes of this complex, interdependent state dynamic are linked, with planning on one end and public contracting on the other, the latter being the most tangible way of concretizing the policies and plans established by the Brazilian state.

Given this, if the starting point is an approach of the economical and financial order in a sustainable manner, the following step is that state planning and, consequently, its budgetary plan, be oriented towards attaining sustainable development. Therefore, concrete action, materialized in public purchases, should also gravitate around such provision, which has been currently referred to as sustainable public contracting.

\section{SUSTAINABLE PUBLIC CONTRACTING}

From understanding state planning as a mean by which the public authorities elaborate their most broad and general goals and objectives, the public contract is, in its turn, one the used tools for the State to concretize and achieve its plan.

Therefore, as we have already covered in the course of planning, the present topic is justified in order to analyze the other end of this dynamic, also linked to sustainable development, hence currently known as sustainable public contracting (or Sustainable Public Tender or Green Public Tender)

\subsection{A new administrative law and sustainable public contracting, a renewed form}

Initially, it is necessary to understand that by thinking sustainable public contracting one speaks of renewed Administrative Law, in which traditional institutes are hence intensely associated with the value of sustainability.

In the words of Freitas (2019), even strict legality, the bulwark of the most basic Administrative Law coursebook, is now associated with sustainability and reappears as a duty of critical observance of norms, setting aside the "all or nothing" discourse, making its interpretation closer to that of the values of the 1988 Political Charter. Henceforth, the public interest itself is not necessarily revealed as an objective of tending the administrative machinery, but the interests of present and future generations.

According to the aforementioned scholar, this new Administrative law has sustainable development as a booster for state dynamics, crossed by new values, with a holistic approach and participative stake holding, in lieu of constricting bureaucracy, power centralization, authority cult and patrimonialism.

Confirming this new tendency, Moreira (2017, p. 18) explains that the conventional standards which regulate the public sector are normally elaborated and executed under static conditions, not considering the relevance of these new changes in the way of governance or the performance of public services. With that, "the new Public Law intends to harmonize state conduct with the changes and vicissitudes of current society", coming closer to "constitutional demands, fundamental principles and rights".

This is justified not only by all the international outcry warning about the risks of the current societal model, founded in unsustainable patterns of consumption and production, but also by values chartered in the Constitution, especially, by the already mentioned intertwining of human dignity and articles 3, 170 and 225. 
That considered, the State may not excuse itself from fulfilling its environmental and ethical duty, being up to it the preservation and protection of a ecologically balanced environment, which is in turn essential for the healthy quality of life of present and future generations. This task cannot be performed without seeking an economical order which ensures a dignified existence to all, geared towards the construction of a free, just and solidary society.

Consequently, the Administrative Law cannot be without this constitutional essence, notably its fundamental principles. And, being so, all its institutes demand a new perception, including Public Tenders.

Freitas (2011), in this line of thought, defines the so-named Sustainable Public Tender as an administrative procedure that, with equality and the effective search for sustainable development, seeks the selection of the most advantageous proposal to the Administration, while reckoning, with utmost objectivity, the cost and social, economic and environmental benefits.

It is in this context that the infra-constitutional lawmakers have promoted a change in article 3 of law 8.666/83, including the promotion of national sustainable development as one of the goals of public contracting.

Art. 3 Public tenders are intended for ensuring the observance of the constitutional principle of equality, the selection of the most advantageous proposal to the Administration and the promotion of sustainable national development, and it will be processed and judged in strict accordance to the basic principles of legality, impersonality, morality, equality, publicity, administrative integrity, entailment to the calling instrument, objective judgement and those related (as written in law 12.349, 2010)

Cherishing the aforementioned legal change, Furtado (2017, p .32) explains that the reformed provision has attained the very object sought by the State, which "started to contain elements which do not strictly relate to the utility that the good or service will provide to the Administration, but to the effects by which their purchase will favor Brazilian society".

It was for no other reason that the law 12.305 of 2010, in instituting the National Policy on Solid Waste, defined that, in article 7, clause XI, one of its objectives is that governmental contracting prioritize the purchase of recyclable products and goods and services considered compatible with patterns of social consumption and environmental sustainability.

Art. 7 The objectives of the National Policy on Solid Waste are:

$\mathrm{XI}$ - prioritization, in governmental purchases and contracting, of:

a) recycled and recyclable products.

b) goods, services and works considered to be compatible with patterns of social consumption and environmental sustainability.

Following this trend, in the federal sphere, the President of the Republic has edited Decree 7746 of 2012, to establish criteria and practices for the promotion of sustainable development in Public Administration contracting.

Theme was further elaborated in non-statutory legislation, having the Ministry of Planning (currently Ministry of Economics) published the Normative Instruction no 01 of 2010 (on sustainability criteria); no 10, of 2012 (Plan of Sustainable Logistics Management) and no 05 of 2017, although it had no direct editions on its theme, it was extremely important in demanding sustainability criteria in service contracting under the indirect execution regime.

Hence, public purchases started to be constituted under the directive of sustainability, and thus, to seek goods and services with a lesser impact on natural resources, giving 
preference to local-sourced technologies and raw materials, as well as those which show greater efficiency in use of water and energy, those which have a greater service life and lower cost of maintenance. Those which reduce pressure on resources and so on.

Therefore, it is under this new Administrative Law that Public Tenders are no longer thought as a mean of satisfying the strict necessities of the administrative machinery, but now, given its new name as Sustainable Public Contracting, it is its duty to promote sustainable development.

Bearing this in mind, the indication is already made that with governmental contracting on one end, in line with state planning on the other, both should follow the same way, that is, a necessary option for sustainability.

\subsection{The planning of public contracting: a necessary option for sustainable development}

We have seen, so far, that the Public Authorities have the duty of preserving and defending an ecologically balanced environment. Equally, the fundamental objective of the Republic, and, therefore, of the Brazilian state, is to build a free, just and solidary society, which ensures national development, eradicates poverty and reduces social inequality.

In order to attain that, the State can make use of one the instruments prescribed in the economic and financial order, state planning, whose article 174 , § 1, qualifies it as necessarily geared towards balanced national development, which, as we insisted and evinced, can only be the sustainable one.

We have seen that while planning finds itself in one of the extremes of this developmental dynamic, public contracting is in the other, with the function of instrumentalizing and fulfilling state planning.

The Budget, in turn, would be the middle point of this track, demanding intensive political articulation able to correlate the use of financial resources to public purchases with a sustainable approach.

But, after all, what would be the strategy or element that can best integrate all this process and dynamics, joining them in favor of sustainable development?

The answer, for us, is the good usage of the State's purchasing capability.

It is estimated that the Union alone turns over resources in the magnitude of $10 \%$ of the GDP (SOUZA, 2015). In consulting the federal government purchase webpage (paineldepreços. planejamento.gov.br), it is declared that, from January to August 2019 more than R 116 billion in public tenders were homologated for the acquisition of goods and service provision for the Federal Public Administration.

Given this, one may note that the State detains a great volume of financial resources, which must meet the demands of the administration and the collectivity. The question, however, is if this power should only tend exclusively to the interests of the administrative machinery or the Administration has an environmental and ethical duty of preserving the planet for present and future generations?

Here, the present work strives in advocating that sustainable public contracting does not lead the public manager to the option of meeting the mere desires of the administration nor obliging the whims of the manager. There is a necessary choice for sustainable development, lest the planetary crisis worsens.

The public authorities, while consumer of goods and services, has, with its purchasing power, the possibility of inducing the market to more sustainable behaviors. 
Biderman (2008, p. 23), by the way, indicates that, in the hands of public authorities concerned with the ecosystem, public contracting represents a powerful instrument for environmental protection, as, given the high sums it turns over, its purchasing power must be used to promote the production of sustainable goods and services. One may even "expect considerable improvement and change in the short- and medium-term market structures".

However, the author warns that it is no use for the State to hold great sums of money if this power is not duly and well used. She observes, concerning this point, that an authority, in general, does not generate innovation, but when several public authorities combine their purchasing power in favor of sustainability criteria, it is possible to think about a change of the consumption and production model (BIDERMAN, 2008)

Carvalho (2009), in this sense, observes that the purchasing power makes the Public Administration a great user and consumer of natural resources, capable of making new forms of production possible, nudging practices in the consuming market, creating demands headed towards sustainability, fostering innovation, generating a multiplying effect and reducing negative socio-environmental impact.

Franco (2013), as well, states that the new article 3 of law 8.666/93, which demands the promotion of sustainable national development, went on to establish that the State purchasing power must be inexcusably linked to socioenvironmental matters.

Mendonça (2018), while advocating that this power must be geared towards the inclusion of sustainability criteria, reports, with examples, how public tenders can conciliate the dimensions of sustainable development. In this sense, the scholar proposes, concerning economic sustainability criteria, scale gains with the adoption of a shared purchase system (gathering several administrative units), process rationality, greater participation and accountability, innovation incentives and preference and fomentation to micro and smalls companies.

Respectively to environmental sustainability criteria, whose field is currently further developed, it is recommended that the public authorities demand from their tenders products of lower environmental impact. For instance, the author mentions pencils, envelopes and other items derived from paper made of legal-sourced wood, preferably recycled. He also advises the purchase of cleaning products with biodegradable tensioactive agents, electrical equipment with the best efficiency ENCE (National Energy Saving Label - Etiqueta Nacional de Conservação de Energia) label, LED lamps, "flex"-type vehicles, electronic versions of newspapers and magazines, batteries that observe the maximum limits of lead, cadmium and mercury and whose supplier mandatorily commits to perform the reverse logistic.

Concerning social sustainability criteria, Mendonça (2018) also mentions a more efficient administrative surveillance on the labor of workers younger than 14 years old, forced or compulsory labor, both forbidden by the legislation. On control, further auditing on the confirmation that the company observes social and working rights, prohibiting racial, ethnic and religious discrimination practices, instructing the outsourced employees on harassment (moral and sexual) practices, demanding a safety plan with supply of EPI, a drinking water supply, mess hall and protection measures for workers against incidents.

In other words, should the State insert in its calls and contracts a significant share of the aforementioned criteria (with no pretension of a complete list), it is possible to say that the public authorities would have, in fact, fulfilled their role in the making of a new consumption model.

From this, it is possible to understand that the sustainability-oriented state purchasing power must integrate and handle the development dynamics from planning to public contracting. 
That is confirmed by Normative Instruction 05 of 2017, published by the Ministry of Planning (current Ministry of Economics), which is, doubtlessly, the most important federal public tender norm. It deals with the regulations concerning service provision under the indirect contracting regime, known as mean-activity outsourcing, broadly used by the direct and indirect Federal Public Administration.

By the mentioned instruction, it is clearly noticeable that public contracting must be linked to state planning, according to clause III of article 1:

Art. 1 Service contracting of the performance of executive tasks under the indirect execution regime, by organs or entities of the direct, foundational and autarchic Federal Public Administration will observe, when applicable:

I - the phases of Contract Planning, Supplier Selection and Contract Management;

II - The sustainability criteria and practices; and

III - alignment with the organ or entity's Strategic Planning, when available.

In addition, the administrative unit must, when performing the initial procedures of contract planning, justify the need for the tender, relating it to the State's strategic planning. Here is article 21, clause I, 'a':

Art. 21. The initial procedutres of Contract Planning consist of the following activities: I - document elaboration for formalizing the demand by the service-requesting sector, compliant with the model of Attachement II, which observes:

a) the justification for the need of contracting, explaining the option for outsourcing the services and considering strategic planning, if that's the case;

Lima (2017), in commenting the provision, explains that said Instruction went on to

demand a more professionalized, efficient and improved public management, especially in developing the process of planning.

The public manager, thus, is now understood as the one who observer and analyzes state planning and seeks to make it concrete through several contracts, which, intertwined, must ensure the effective provision of goods and services to society (article 165, §10 of the Constitution);

Therefore, if the purchasing power is not well utilized by the public authorities, this provision of goods and services to society will only reproduce the current consumption model, unsustainable and coherent with the idea of mere growth.

Besides, as already stated, the state purchasing power must be the strategic element that integrates this entire dynamic, from planning to contracting. This means that if the planning is not imbued with the purpose of ensuring sustainable development, it is possible and probable that public contracting won't be as well.

That is, should the purchasing power not be purposed for attaining sustainability, the managers themselves won't make efforts to fulfill said purpose. With this, sustainable public contracting will be no more than mere, faint initiatives in the field of public administration.

That is why, from planning to public contracting, there's a necessary option for sustainable development, lest not only we breach fundamental principles, but worsen the socioenvironmental crisis the planet experiences.

\section{FINAL CONSIDERATIONS}

In recognizing that the planet suffers under severe social, economic and environmental problems, the international community has debated ways of facing them, especially with the 
effort of leaving behind the old mere economic growth practices and going on to influence a new model, based on sustainable development.

In Brazil, a good part of the doctrine has noted the need for the country to adopt a new role which can, effectively, fight the social and environmental crisis, which, one may say, are not limited to geographical markings, but permeate all nations in the world.

Given that, a new interpretative approach is cast on the 1988 Constitution, articulating a logical and systematical intertwining of articles 1, 3, 170 and 225, in a way that sustainable development is made into a fundamental principle to be attained by the Brazilian republic.

That is, the ethical duty of the state to preserve and protect an ecologically balanced environment is necessarily linked to an economic order directed towards ensuring a dignified existence, along with the fundamental objectives of our Charter: the making of a free, just and solidary society, which ensures national development, eradicates poverty and reduces social and regional inequality. All this, obviously, linked to the principle of human dignity.

From there, the present study evinced that one of the institutes of the economic and financial order, namely state planning, has an important role of reshaping state action. Therefore, efforts must be made in promoting it as a technique of rationalizing public policy, making it more efficient and effective.

Besides, by interpreting article 174, its beginning and $\S 1$, of the Constitution, state planning must be necessarily geared towards balanced national development, which was shown to be the sustainable one. In this way, all matters which contact it must also take this provision into consideration.

Budgetary planning, for instance, if analyzed in the present study by its strong link to public contracting, also shows its link to sustainability, as the budgetary laws (PPA, LDO and LOA) are oriented towards reducing social and regional inequality.

In addition, considering that planning is the most broad and abstract point, by declaring the budget's goals and broad objectives, the public contract, on the other hand, shows itself to be the most concrete and specific act, whose objective is precisely toe make the state plan concrete and effective.

With this intention, if the whole legal system is linked to sustainable development, the same should be with Administrative Law. New renewed, it goes on to reform its most traditional institutes, including public tenders, re-signifying them as Sustainable Public Contracting.

Given this outlook, it was shown that the State, given the large sums of public resources it turns over, holds the so-called purchasing power, capable of influencing and nudging the market to adopt a new consumption model, being sustainable and complying with the Charter values.

In order to make it so, it was noted that the purchasing power must integrate the state development dynamic, promoting interaction from planning to public contracting.

That is, if sustainable development is not the crux of planning, possibly it won't be so for public contracting, since the managers, those of have the role of making the state plan concrete (by mean of several contracts), they will be not be engaged in this purpose.

Therefore, if the purchasing power, even if obviously oriented towards attaining sustainable development, does not correspond to the strategic planning of this complex and interdependent process, one may affirm that sustainable public contracting will be no more than a faint initiative of a few agents in the scope of the Public Administration.

Thus, the conclusion that, from state planning to public contracting, there's a necessary option for sustainable development, is drawn. 


\section{REFERENCES}

ADRI, Renata Porto. O planejamento da atividade econômica como dever do Estado. Tese (Doutorado em Direito do Estado). Pontifícia Universidade Católica de São Paulo, São Paulo, 2007.

BIDERMAN, Rachel et al. Guia de compras públicas sustentáveis: uso do poder de compra do governo para a promoção do desenvolvimento sustentável. 2.ed. Rio de Janeiro: FGV, 2008.

CARDOSO JÚNIOR. José Celso. Planejamento governamental e gestão pública no Brasil: Elementos para ressignificar o debate e capacitar o Estado. Texto para Discussão 1584, Instituto de Pesquisa Econômica Aplicada, Brasília, 2011.

COMISSÃO MUNDIAL SOBRE MEIO AMBIENTE E DESENVOLVIMENTO. Nosso futuro comum. 2. ed. Rio de Janeiro: Fundação Getúlio Vargas, 1991.

CRUZ, Paulo Márcio e FERRER, Gabriel Real. Direito, Sustentabilidade e a Premissa Tecnológica como Ampliação de seus Fundamentos. Sequência (Florianópolis), n. 71, p. 239-278, dez. 2015.

FEITOSA, Maria Luiza Alencar Mayer. Direito econômico do desenvolvimento e direito humano ao desenvolvimento. Limites e confrontações. In: Maria Luiza Alencar Mayer Feitosa et al. (orgs.). Direitos humanos de solidariedade: avanços e impasses. Curitiba: Appris, 2013, pp. 171-240.

FRANCO, Caroline da Rocha. Licitações ecoeficientes e as políticas públicas ambientais. A\&C : Revista de Direito Administrativo \& Constitucional. - ano 13, n. 51, (jan./mar. 2013), Belo Horizonte: Fórum, 2013.

FREITAS, Juarez. Sustentabilidade: Direito ao futuro. 4. ed. Belo Horizonte: Fórum, 2019.

FREITAS, Juarez. Licitações e sustentabilidade: ponderação obrigatória dos custos e benefícios sociais, ambientais e econômicos. Interesse Público - IP, Belo Horizonte, ano 13, n. 70, nov./ dez. 2011. Disponível em: <http://www.bidforum.com.br/PDIooo6.aspx?pdiCntd=76861>. Acesso em: 31 ago. 2019.

FURTADO, Lucas Rocha. Curso de licitações e contratos administrativos. -7.ed.rev.atual. e ampl.- Belo Horizonte: Fórum, 2017.

GRANZIERA, Maria Luiza Machado. Direito ambiental. - 3.ed. rev. e atual. - São Paulo: Atlas, 2014 .

GRAU, Eros Roberto. A ordem econômica na Constituição de 1988. 11.ed. São Paulo: Método, 2006.

LEITE, Harrison. Manual de Direito Financeiro. 6.ed. Salvador: JusPODIVM, 2017. 
LIMA. Fábio de Andrade. Os 17 anos do Termo de Referência: evolução histórica e a repercussão da IN SEGES/MP no 05/2017. In: Terceirização: Legislação, doutrina e jurisprudência. FERNANDES, Jorge Ulisses Jacoby (Coord.). Belo Horizonte: Fórum, 2017.

MARRARA, Thiago. A atividade de planejamento na administração pública: $O$ papel e o conteúdo das normas previstas no anteprojeto da nova lei de organização administrativa. In: Revista eletrônica de Direito do Estado, n. 27 - julho/agosto/setembro de 2011 - Salvador, 2011.

MEIRELLES, Hely Lopes. Direito administrativo brasileiro. 4o. ed. São Paulo: Malheiros, 2014 .

MENDONÇA, Carmen Thereza Pietsh Cunha. A sustentabilidade no Processo de Compras em Instituições Federais de Ensino Superior do Centro-Oeste. Dissertação (Mestrado). Universidade Federal de Goiás. Goiânia, 2018.

MILARÉ, Édis. Direito do ambiente. 9.ed.rev., atual. e ampl.- São Paulo: Editora Revista dos Tribunais, 2014.

MIRANDA, Nara Oliveira. Compras públicas sustentáveis: Barreiras e oportunidades de melhoria no âmbito das organizações militares da Marinha. Dissertação (Mestrado). Escola Brasileira de Administração Pública e de Empresas da Fundação Getúlio Vargas - FGV. Rio de Janeiro, 2018.

MOREIRA, Rafael Martins Costa. Direito Administrativo e sustentabilidade: o novo controle judicial da Administração Pública. Belo Horizonte: Fórum, 2017.

NUSDEO, Fábio. Desenvolvimento econômico: Um retrospecto e algumas perspectivas. In: SALOMÃO FILHO, Calixto (Coord.). Regulação e desenvolvimento. São Paulo, Editora Malheiros, 2002.

PAIVA JÚNIOR, Luiz Carlos de Oliveira. O direito fundamental ao meio ambiente ecologicamente equilibrado: da previsão constitucional à garantia de sustentabilidade. Dissertação (Mestrado). Universidade Federal do Rio Grande do Norte, Natal, 2018.

PEREIRA, Romilson Rodrigues. Orçamento público e os paradigmas do desenvolvimento sustentável. In: Revista do TCU, ano 40, n.112, mai/ago, Brasília, 2008.

SILVA, Guilherme Amorim Campos da. Direito ao desenvolvimento. São Paulo: Editora Método, 2004.

SOUZA, Lilian Castro de. Política nacional do meio ambiente e licitações sustentáveis. In: SANTOS, Murillo Giordan; VILLAC, Teresa (Coord.). Licitações e contratações públicas sustentáveis. 2. ed. Belo Horizonte: Fórum, 2015. p. 103-115.

TAVARES, André Ramos. Direito constitucional econômico. 3.ed. Rio de Janeiro: Forense; São Paulo: Método, 2011. 
VARELLA, Marcelo Dias. Direito internacional econômico ambiental. Belo Horizonte: Del Rey, 2003.

VIEIRA, André Luís. A ponderação entre preservação ambiental e desenvolvimento na ordem constitucional. Fórum de Direito Urbano e Ambiental - FDUA, Belo Horizonte, ano 9, n. 5o, p. 1324, mar./abr. 2010. 